$\mathrm{O}$ gólnopolska Konferencja Naukowa na temat „Niewygodne dla władzy. Ograniczanie wolności słowa w Polsce w XIX i XX wieku" została zorganizowana $\mathrm{w}$ dniach $18-19$ listopada 2008 r. przez Instytut Informacji Naukowej i Bibliologii Uniwersytetu Mikołaja Kopernika w Toruniu. Komitet naukowy konferencji tworzyli: prof. dr hab. Grażyna Gzella, dr hab. Jacek Gzella, prof. dr hab. Bronisława Woźniczka-Paruzel oraz dr hab. Iwona Imańska. Funkcję sekretarzy konferencji pełnili oraz odpowiedzialni za jej organizację byli dr Dorota Degen oraz mgr Marcin Żynda.

Gości konferencji przywitała prof. dr hab. Bronisława Woźniczka-Paruzel, dyrektor Instytutu Informacji Naukowej i Bibliologii UMK. Następnie głos oddano przedstawicielom władz uczelnianych - prorektorowi prof. dr. hab. Witoldowi Wojdyle oraz prodziekanowi Wydziału Nauk Historycznych dr. hab. Stanisławowi Roszakowi. Minutą ciszy uczczono pamięć zmarłego 24 lipca 2008 r. profesora Uniwersytetu Humanistyczno-Przyrodniczego Jana Kochanowskiego w Kielcach Stanisława Adama Kondka, adiunkta Biblioteki Narodowej, prezesa Polskiego Towarzystwa Bibliologicznego, który wcześniej zgłosił swój udział w konferencji.

$\mathrm{Na}$ przedpołudniowe, plenarne obrady pierwszego dnia złożyło się siedem wystąpień, chronologicznie mieszczących się w okresie od pierwszej połowy XIX w. do 1990 r. Dotyczyły one: cenzury wydawnictw w Galicji w pierwszej połowie XIX stulecia (Roman Jaskuła w swym referacie pod-

\section{Ogólnopolska Konferencja Naukowa „Niewygodne dla władzy. Ograniczanie wolności slowa w Polsce w XIX i XX wieku" (Toruń, 18-19 listopada 2008 r.)}

kreślił istniejące braki $\mathrm{w}$ badaniach nad cenzurą z tego okresu); działań cenzury na szczeblu lokalnym w latach 1918-1939 na przykładzie Krakowa (wystąpienie Grażyny Wrony); konfiskat w wileńskim „Słowie” z lat 1936-1939 (Jacek Gzella); restrykcji wobec ruchu piśmienniczego w Generalnym Gubernatorstwie w latach 1939-1945 (Krzysztof Woźniakowski); funkcjonowania Głównego Urzędu Kontroli Prasy, Publikacji i Widowisk w latach 1945-1990 (Zofia Sokół); losów i postaw pisarzy polskich w PRL-u (Tomasz Mielczarek) oraz upaństwowienia przedsiębiorstw wydawniczo-księgarskich i poligraficznych w Poznaniu w latach 1946-1950 (Piotr Nowak).

W trakcie dyskusji po obradach plenarnych podkreślono wpływ ingerencji cenzorskich na wzrost nakładu pism, które czytano chętniej z powodu licznych konfiskat. Nie zabrakło głosów pokazujących niszczącą rolę cenzury, także pod względem finansowym (konfiskata całego tytułu, kary pieniężne dla redakcji, koszty procesów sądowych). Poruszono wreszcie problemy metodologiczne. Zastanawiano się, jak liczyć konfiskaty - czy uwzględniać w statystyce numer jako 
jedną pozycję, czy też liczyć każdy zajęty artykuł osobno.

Popołudniowe obrady odbywały się w dwóch sekcjach. W sekcji I znalazły się wystąpienia dotyczące ograniczania wolności słowa do 1939 r., w sekcji II - cenzury w czasach PRL-u (z naciskiem na pierwsze 10 lat).

W sekcji I, której przewodniczyła dr hab. Grażyna Wrona, wysłuchano dziesięć referatów. Ich tematyka oscylowała wokół problemów funkcjonowania cenzury w trzech zaborach: rosyjskim (Janusz Kostecki, Robert Stopikowski, Artur Markowski, Małgorzata Rowicka, Andrzej Kaleta), pruskim (Grażyna Gzella, Bogumił Pronobis), austriackim (Marcin Soboń), w okresie pierwszej wojny światowej (Damian Szymczak) i w dwudziestoleciu międzywojennym (Lech Krzyżanowski, Marcin Żynda).

W sekcji II, której przewodniczył dr hab. Krzysztof Woźniakowski, wygłoszono dwanaście referatów. Ich autorzy mówili o ingerencji cenzury w teksty zamieszczane w czasopismach (Evelina Kristanova, Maciej Fic, Mariusz Trąba, Iwona Pietrzkiewicz, Michał Rogoż, Jacek Ladorucki), o kłopotach poszczególnych autorów (Magdalena Mateja, Przemysław Koniecki, Jolanta Chwastyk-Kowalczyk) czy też problemach instytucji i wydawnictw (Dorota Degen, Wanda A. Ciszewska, Krzysztof Okoński).

W drugim dniu konferencji wygłoszono pięć referatów w ramach obrad plenarnych. Wszystkie dotyczyły okresu PRL-u. Zajęto się między innymi: przedstawianiem wydarzeń hi- storycznych na łamach podręczników do nauczania historii (Anna Glimos-Nadgórska - problem Katynia; Joanna Górska - postać Józefa Piłsudskiego), oczyszczaniem księgozbiorów z książek szkodliwych politycznie (Małgorzata Derkacz), spisami bibliograficznymi w czasach PRL-u (Jadwiga Sadowska) oraz ingerencjami cenzury w „Gwiazdę Morza” (Zdzisław Kropidłowski).

W dyskusji po obradach plenarnych dnia drugiego zwrócono uwage na kwestię celowego zawyżania nakładów niektórych pism czy dzieł w czasach PRL-u, a w niektórych przypadkach (jak np. „Sztuki kochania” M. Wisłockiej) - ich zaniżania.

Podczas dwóch dni konferencji wysłuchano trzydziestu czterech prezentacji (z zaplanowanych trzydziestu siedmiu), przygotowanych przez przedstawicieli piętnastu ośrodków naukowych i wyższych uczelni z kraju. Dotyczyły one podstaw prawnych funkcjonowania cenzury, polityki władz wobec prasy i książki, relacji między autorem a cenzurą czy wreszcie konkretnych ingerencji cenzorskich w wybrane tytuły. Uczestnicy wyrazili potrzebę kontynuowania podobnych spotkań, analizowania nowych obszarów badawczych i podjęcia dyskusji metodologicznej.

\section{Joanna Edwarczyk}

studentka II roku uzupełniających studiów magisterskich informacji naukowej i bibliotekoznawstwa $w$ Instytucie Informacji Naukowej i Bibliologii Uniwersytetu Mikołaja Kopernika w Toruniu 